Seloka: Jurnal Pendidikan Bahasa dan Sastra Indonesia

9 (2) (2020) : $140-146$

UNNES

http://journal.unnes.ac.id/sju/index.php/seloka

\title{
Impact of Social Media on Basic School Children's Language Achievement
}

Hidayat Nur Septiadi $^{1 凶}$, Khairul Utomo ${ }^{1}$, Fakhri Fakhrur Rozy ${ }^{2}$, Arfian Arrosid Nurd ${ }^{2}$, Alfa Rosyid Abdullah ${ }^{2}$

DOI: https://doi.org/10.15294/seloka.v9i2. 28028

1. Sekolah Tinggi Keguruan dan Ilmu Pendidikan (STKIP) Darussalam, Cilacap, Indonesia

2. Pascasarjana Pendidikan Bahasa Indonesia, Fakultas Keguruan dan Ilmu Pendidikan, Universitas Sebelas Maret Surakarta, Indonesia

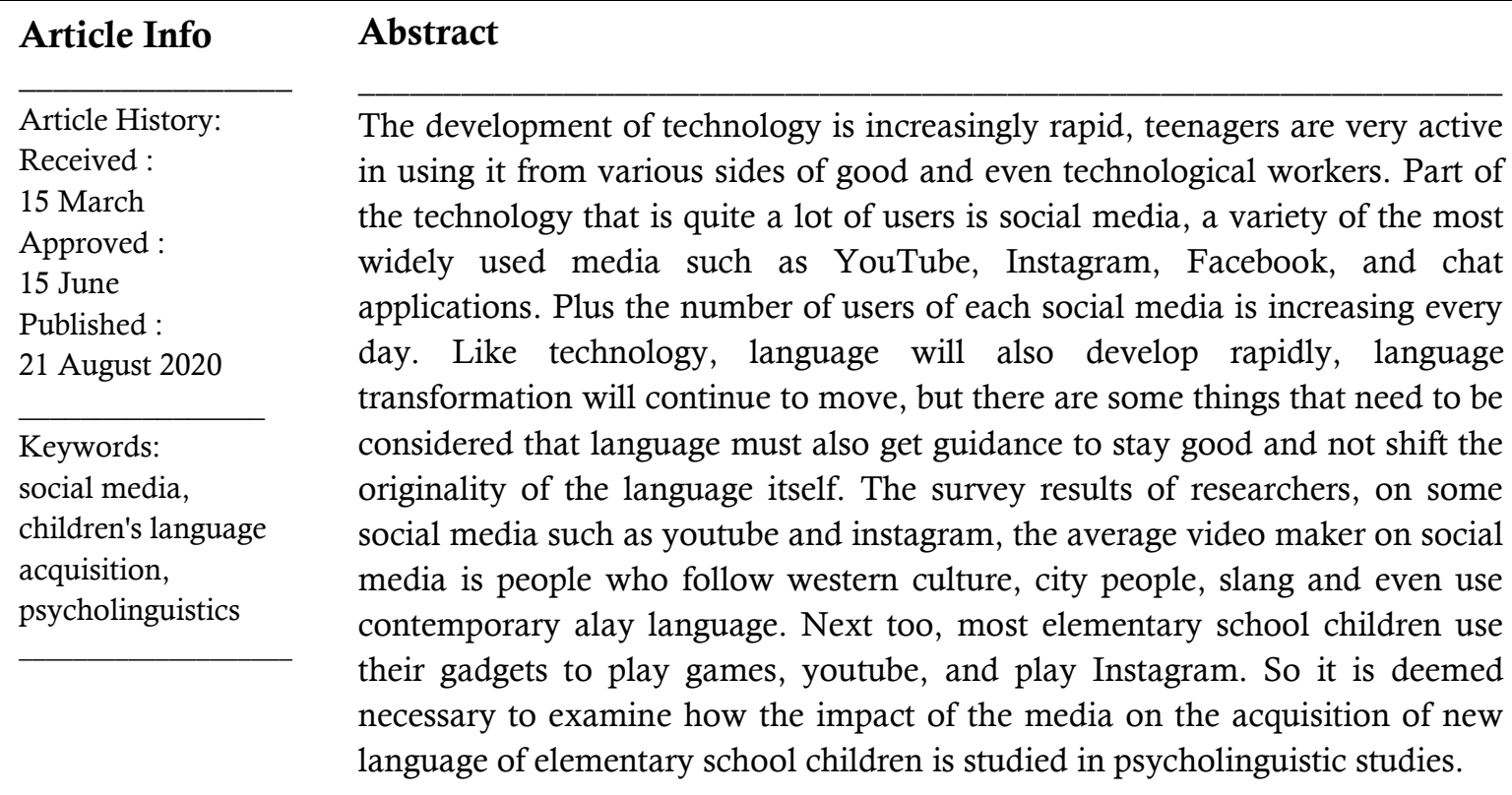

Correspondence address:

p-ISSN 2301-6744

Sekolah Tinggi Keguruan dan Ilmu Pendidikan (STKIP)

Darussalam, Cilacap

e-ISSN 2502-4493

E-mail: hidayatnurseptiadi28@gmail.com 


\section{INTRODUCTION}

The development of technology is increasing rapidly. Teenagers are very active in using it from various sides, both in terms of technology and even labor. Not only teenagers, but even elementary school children also take advantage of technology without certain limitations. This is because it has the support of parents to get an Android-based smartphone so that it has many features.

The part of smartphone technology that has quite a lot of users is social media. Social media is a form of development of science and technology in the industrial era 4.0 which is often used by the community as a medium of interaction (Isnaini, Mardikantoro, \& Santoso, 2020). Various kinds of media that are most widely used such as YouTube, Instagram, Facebook, and WhatsApp chat applications. Masluchah, Supriyanto, \& Yuniawan (2020) in his research said that the trend of video blogs (vlogs) in Indonesia, be it YouTube or other social media, has been accepted by the majority of young people.

The number of users of each social media is increasing every day. In the Liputan6.com survey, it was stated that there were around 55.39 percent of the total respondents access the internet for more than six hours. Meanwhile, other respondents were more varied, ranging from 2 to 6 hours a day (Damar, 2017). Statistical data released by the NPD Group on the use of digital media by children aged 2-14 years shows a significant increase in the use of video games, computers, and digital music players. (Efendi, Astuti, \& Rahayu, 2017). This can mean that internet usage is increasingly prevalent and has become a trend in the world, including Indonesia as one of the largest internet consumers in the world.

In general, the use of social media can be said to be good if it is used for good things, such as chatting, learning, introducing culture to tourism, learning languages, and so on. But nowadays, the use of social media has damaged its users with adult videos, bullying, blasphemous news, hoaxes, and even damages the use of language. The development of social media has both positive and negative impacts on children at elementary school age (Fitri, 2017). Chusna (2017) states that smartphones not only harm children but also have a positive impact, including in the child's mindset, namely being able to help children improve their right brain abilities while under good supervision. To be able to use smartphones effectively, parents should be able to understand and explain the content on the smartphone. To minimize unwanted things (Haq, 2017).

Besides, Kusuma and Ardhy (2011) recommend that everyone reduce the light level on their cellphones to a low level so that they are not so disturbing at night. When resting, it's a good idea to keep your cellphone on a razor blade or keep it away from the bed. Especially for children who are still in elementary school. Eye health is very important to maintain, don't get irritated because you play too often on smartphones. Sugiono, Prayanto, and Yudani (2015) argue that adult dependence on smartphones in children makes them think that smartphones are everything for them. They will be nervous if separated from the smartphone. Addiction to smartphones makes children easily bored, anxious, and irritable when separated from their favorite smartphone (Hastuti, 2012).

But on the other hand, the children will get more vocabulary. Children will continue to read the information on their smartphones, especially related to learning needs or assignments from school.

Tarigan (2011) explains that the acquisition of children's language can be said to have a series of unity that moves from one speech kata sederhana menuju gabungan kata yang lebih rumit.

It is undeniable that language will continue to develop rapidly with technology, language transformation will continue to move, but there are several things to note that language must also receive guidance so that it remains good and does not shift the originality of the language itself. Social media has quite an important role in the development of a language, wherewith social media language users will learn or imitate the 
languages they want to know, the YouTube and Instagram platforms have the most role in language development because they are videobased which utilize audio and visuals so that easy to imitate again.

The presence of social media among adolescents makes a person's private space fuse with public space (Ayun, 2015). Therefore, social media is used by elementary school children, there have been many role models (elementary school) children such as vloggers or video maker communities as their new style. Dewi, Neviyarni, \& Irdamurni (2020) Children will quickly pick up on what they see and listen to because phases 6 12 are primary school age which is a period of the rapid development of abilities know and mastering vocabulary (vocabulary). Besides, elementary school children today prefer or follow trending artist figures on YouTube and Instagram such as Atta Halilintar, Ria Ricis and others. By claiming to be fans, children will prefer to imitate their activities, style of clothing, to their language.

Elementary school children tend to easily acquire language at school, as expressed by Yusuf (2011), arguing that in schools, language lessons are given which deliberately increase vocabulary, teach sentence structure, proverbs, literature, and writing skills. By being equipped with this language lesson, it is hoped that students can master and use it as a tool to communicate with others, express their hearts (feelings), understand the skills to process the information they receive, think (express ideas or opinions), develop their personalities, such as expressing attitudes and his belief. (his feelings). However, it cannot be denied that children's language acquisition is also obtained from factors outside of school because children do not get up to $50 \%$ of vocabulary at school, but instead get it at home or in life outside of school, this also includes the use of gadgets that are trending among them. The results of the researcher's survey, on several social media such as YouTube and Instagram, are the average maker videos on social media are people who follow western style, urbanites, slang, even use contemporary Arabic so that videos are interesting to watch. In addition, elementary school children use their gadgets the most to play games, YouTube and play Instagram. Therefore, researchers feel interested in examining how the impact of these media on the acquisition of new languages for elementary school-age children studied in psycholinguistic studies.

On the other hand, the use of today's technology media is also not all bad because it is also very useful for the development of students in schools, as in Abdullah's research (2018) which states that vlogs on the YouTube platform can be used as a medium used to develop students' language skills because short, concise, clear and creative so that it has its charm. Likewise, research by Kusnida, Mulyani, \& Su'udi (2015) which utilizes audio-visual media as a learning medium and is very effective as a medium for learning to write short stories containing character education. In line with these two studies, Barliana (2015) in her research said that the development of short story audio learning media that contains character education values can be utilized as a very attractive medium because it is innovative, capable of developing power imagination and develop the value of knowledge, skills, and attitudes of students.

There are several articles related to language acquisition, language on social media, the influence of social media regarding this research. Setyawati (2016) in her research, states that the factors behind the use of slang on social networks are: (a) to strengthen relationships, look for forms of identity, express self-expression; (b) to convey matters that are considered closed to other age groups or so that other parties cannot find out what they are talking about; and (c) for the purpose of concealment or antics.

Putri, Nurwati, and Budiarti (2016) stated that teenagers become hyperactive on social media, often posting their daily activities that seem to describe their lifestyle trying to keep up with the times, so they are considered more popular in their environment. However, what they post on social media does not always reflect the true state of their social life. When these teenagers post their joyful side of life, it is not uncommon for them to feel lonely in their lives.

Elendea, Esti, Nugroho, and Probo (2011) state that the use of slang in everyday life hurts 
sustainability Indonesian. For example, in a conversation activity the usual what is done by adolescents, when adolescents express feelings to the opposite sex or are about to start a conversation, they use the words to pronounce and gloat, then this already reflects that the use of slang has a negative effect, namely the loss of standard language rules in the community.

Based on this background, the researcher presents a formulation of the problem "how is the impact of social media on language acquisition of elementary school children in the village of Sukowiryo?"

\section{METHOD}

The methodological approach used in this research is descriptive qualitative, producing descriptive data in the form of written or spoken words from the observed person or actor by exploring the object. According to (Marshall and Rossman Creswell, 2014). Qualitative research frames study with fundamental assumptions such as new designs and the presentation of various realities, in this case, the position of the researcher as one of the data collection instruments and focus on the views of the participants.

The object of this research is the use of the language of 7 elementary school children in RT 2 Sentong hamlet, Sukowiryo village, Bondowoso Regency. The choice of objects at this location is because Sukowiryo village can be said to be the border between rural and urban life, so that today's technological developments have spread and elementary school children in the village are very thick with Madurese as their daily life and Indonesian as their additional language for communicating, as a person who is very vulnerable to being affected by technological developments.

Researchers chose several children to be the right objects to see how their language was developing because of the impact of watching YouTube and other social media. This selection uses a purposive random sampling technique, which is a technique of taking random objects but based on considerations or based on certain strata which are usually carried out for reasons of time, energy, or funds (Suharsimi, 2016).

This research focuses on research on the results of speech on the object of research, at first, the researcher looks for or observes some very popular speech on social media, then matches the speech of the research object, to what extent they imitate these languages.

\section{RESULTS AND DISCUSSION}

In this study, the object under study was the language of children 6-12 years in RT 9 Sukowriyo village, Bondowoso. Some of these children are Aurel (6 years), Nana (7 years), Aulia (9 years), Daffa (10 years), Marcel (11 years), Rizki (11 years), and Fauzan (12 years). The seven children live in the same RT, their mother tongue is Madurese, their daily language use is Madurese and Indonesian, and they have almost the same portion of gadget usage. With the support of parents to have a cellphone has an impact, namely, they are faster to catch new things and those that are viral on several social media. The background of the village of Sukowiryo itself is a village that is included in the urban area so that village life has transitioned to life or trends in the city. The everyday language they use is a mixture of Indonesian and Madurese.

In this study, the authors found some of their utterances, which they absorbed directly on social media such as vlogs, games, parodies, and so on. Some of the findings and analyzes are described below.

1. Lo Gue: the word is sometimes used by them when playing with friends who are equally cool according to them, or friends familiar with them. Indeed, like on social media, these two words are usually used by Jakarta children to greet, they (the object of research) also accept and use the cool word to replace the words you and I, including the tone used in Jakarta. It is not surprising that on some social media, elementary school children were able to imitate TV or film actors fluently even though they were not from Jakarta. 
2. Gaes: they say the word when they are together, a greeting for everyone, the meaning is the same as "hei kalian", the use of the word "gaes" is used when one person calls several friends, for example "gimana gaes". The word is usually used by some creators of the youtube video that they watch frequently, and the word "gaes" indeed it is used to open videos or greet their viewers, so that the object of the researcher is found trying to use the word in their daily lives.

3. Rank: the word means level or ranking, they often mention to discuss games. Example "kamu rank apa ?". These words appear they use usually among boys when played game AOV or Mobile legend in the sense of asking what level they have reached in the game.

4. Ndasmu: This word is often used by Fauzan when he is excited about playing games, which means your head, on Instagram, there is a video that shows parents who often use the word when they are excited when playing games. Word "ndasmu" is a Javanese language, Fauzan as a Madurese child does not know the meaning of the word, but because it is fun he says it and mimics what is on the Instagram video. This is imitated spontaneously, as a form of annoyance when playing.

5. Kuy: the word is Malanganese (Malang city or language inverse), Malangan language is a language that reverses the word like nakam (eat), tahes (healthy), oyi (yes), ayas (me) etc. The word is the opposite of the word " $y u k$ " which means invitation, word usage "kuy" used when they invite friends out. On social media, the words are often used in chat, Instagram, and YouTube videos, as connoisseurs of social media, they use or imitate the word several times.

6. Coy: This word is rarely used, but once uttered, it has almost the same meaning as bro or sis, sometimes they call their peers with words coy. Example "coy, mau kemana", The word has a familiar nickname, suitable for colleagues, so they feel slang and have the same social degree.

7. Yoi: has the same meaning as the word yes, sometimes they use it to confirm or approve an invitation or question. Boys used to mix up these words with wordssometimes they call their peers with words "bro", so that being said "yoi bro!".

8. Anjay: The word is often used by boys when referring to something luxurious or amazing, there is no exact meaning of the word. This word was first popular since the release of a song by YouTube creator named Kemal Palevi, some lyrics say "sepatuku anjay", can be interpreted to admire the luxury of these shoes, by calling it "anjay". The children studied appeared when they chatted about game, A say "aku udah rank Mithic loh", suddenly B said "anjay bro! mantap!".

9. Anjir/Njir: the word appears when they are upset or respond to things that make them laugh. For example, when a friend makes a joke, they use the word "eh, anjir banget kau!", there is no definite meaning of the word, but because it is popular on social media, they like to imitate it.

10. Ngekes: the language you get from watching live gaming videos on YouTube. The word comes from the word cash in English which has the intention of paying to get special items from the game. Usually, the goods purchased with direct money provide an advantage over the items that are obtained free of charge from the game. Word "cash" get the affix ng- which is meant to be done or has been done.

11. Nub: This word is obtained from videos on Youtube. Live gaming videos often use this word to describe poor gaming skills. Players who are still amateur or beginner often get nicknames "noob" because there is not much knowledge obtained from the game. Word "noob" derived from the word "newbie" which means beginner. When in the real world some friends make mistakes or 
carelessness, the noob's name will be pinned to the friend.

12. Wotdefak: This word comes from an English word "what the fuck" which is a curse from the United States. This word or term is often uttered by YouTubers when they experience defeat or technical errors while playing games. This word is an expression of frustration or disappointment when there is an error from oneself or a group friend. This word is often used by these children when they are disappointed or upset about the actions of themselves or others.

13. Mabar: This word has the acronym play together. The term is derived from the acronym play together, but children make it another term that is more often expressed in their daily lives. The term comes from live gaming YouTube videos that often invite friends or viewers to play together in a group. When they invite friends to play together, phrases appear "mabar yuk" as an invitation.

These findings have a good effect if they can understand multiple languages and their restricted uses. However, it will be bad if they wear out Indonesian and the regional languages they often use, other things that make this language uncomfortable to hear when used with older people because the principle of politeness in language is considered impolite. Elementary school children need to pay attention to the use of language is the guidance of their parents and those around them to remain polite and polite, and limit the use of these languages to continue to love regional languages and Indonesian as the state language.

\section{CONCLUSION}

The development of technology is one of the causes of the rapid development of language. One of the technologies that are the center of language distribution is social media, all Indonesian people have used gadgets to have fun, children aged 6-12 also use it so that it has quite an influence on the language of children who are more likely to follow along. Researchers found ten languages that are quite popular among children, such as "loe gua, gaes, anjay, njir" etc. The influence of social media has quite a positive and negative impact, positive if children can understand a lot restricted language and usage, whereas it is negative if they speak Indonesian and regional languages that they often use and if the language is used to older people because the principle of politeness in the language is considered impolite. Guidance from their parents and those around them to remain polite and polite, and limit the use of these languages so that they still love the regional language and Indonesian as the national language.

\section{REFERENCES}

Abdullah, A. R. (2018). Vlog Sebagai Media Pembelajaran Bahasa Indonesia Untuk Mengembangkan Kemampuan Berbahasa Peserta Didik. Prosiding Seminar Nasional Kajian Bahasa, Sastra Dan Pengajarannya (2018), (April 2018), 2-5. Surakarta: Universitas Muhammadiyah Surakarta.

Ayun, P. Q. (2015). Fenomena Remaja Menggunakan Media Sosial dalam Membentuk Identitas. Channel: Jurnal Komunikasi Universitas Ahmad Dahlan, 3(2), $1-16$.

Barliana, L. (2015). Pengembangan Media Pembelajaran Audio Cerita Pendek Yang Bermuatan Nilai-Nilai Pendidikan Karakter. Seloka: Jurnal Pendidikan Bahasa Dan Sastra Indonesia, 4(1), 1-7.

Chusna, P. A. (2017). Pengaruh Media Gadget pada Perkembangan Karakter Anak. Dinamika Penelitian: Media Komunikasi Sosial Keagamaan, 17(2).

Creswell, J. W. (2014). Research Design: Pendekatan Kualitatif, Kuantitatif, dan Mixed Methods (A. Fawaid, Ed.). Yogyakarta: Pustaka Pelajar.

Damar, A. M. (2017). Berapa Lama Orang Indonesia Akses Internet dalam Sehari? Retrieved from liputan6.com website: https://www.liputan6.com/tekno/read/ 
2823867/berapa-lama-orang-indonesiaakses-internet-dalam-sehari

Dewi, M. P., Neviyarni, \& Irdamurni. (2020). Perkembangan Bahasa, Emosi, dan Sosial Anak Usia Sekolah Dasar. Jurnal Ilmiah Pendidikan Dasar, VII(1), 1-11.

Efendi, A., Astuti, P. I., \& Rahayu, N. T. (2017). Analisis Pengaruh Penggunaan Media Baru terhadap Pola Interaksi Sosial Anak di Kabupaten Sukoharjo. Jurnal Penelitian Humaniora, 18(2), 12-24.

Elendea, A., Esti, D., Nugroho, N. C., \& Probo, A. (2011). Pengaruh Bahasa Opera Van Java terhadap Penggunaan Bahasa Indonesia di Masyarakat. Retrieved from berkarya.um.ac.id website: https://berkarya.um.ac.id/pengaruhbahasa-opera-van-java-terhadappenggunaan-bahasa-indonesia-dimasyarakat/

Fitri, S. (2017). Dampak Positif dan Negatif Sosial Media terhadap Perubahan Sosial Anak. Naturalistic: Jurnal Kajian Dan Penelitian Pendidikan Dan Pembelajaran, 1(2), 118-123.

Haq, M. K. J. (2017). Pengaruh Penggunaan Media Smartphone sebagai Sumber Belajar terhadap Motivasi Belajar dan Prestasi Akademik Mata Kuliah Studi Fiqh Mahasiswa Jurusan Pendidikan Agama Islam UIN Maliki Malang. Universitas Islam Negeri Maulana Malik Ibrahim Malang.

Hastuti. (2012). Psikologi Perkembangan Anak. Yogyakarta: Tugu Publisher.

Isnaini, F., Mardikantoro, H. B., \& Santoso, B. W. J. (2020). The Form of Code Choice in Ganjar Pranowo Social Media Twitter. Seloka: Jurnal Pendidikan Bahasa Dan Sastra Indonesia, 9(1), 28-35.
Kusnida, F., Mulyani, M., \& Su'udi, A. (2015). Keefektifan Penggunaan Media Audio Visual Dan Media Komik Strip Dalam Pembelajaran Menulis Cerpen Yang Bermuatan Nilai-Nilai. Seloka: Jurnal Pendidikan Bahasa Dan Sastra Indonesia, 4(2), 111-117.

Kusuma, Y., \& D. Ardhy, A. (2011). Internet untuk Anak Tercinta. Jakarta: PT Gramedia Widiasarana Indonesia.

Masluchah, U. N. L., Supriyanto, T., \& Yuniawan, T. (2020). Anecdotes in Youtube Videos in Javanese " Cenut Nut " (Sociolinguistic Study). Seloka: Jurnal Pendidikan Bahasa Dan Sastra Indonesia, 9(5), 1-8.

Putri, W. S. R., Nurwati, R. N., \& Budiarti, M. (2016). Pengaruh Media Sosial terhadap Perilaku Remaja. Prosiding Penelitian Dan Pengabdian Kepada Masyarakat, 3(1), 47-51. Retrieved from http://jurnal.unpad.ac.id/prosiding/artic le/view/13625/6455

Setyawati, N. (2016). Pemakaian Bahasa Gaul dalam Komunikasi di Jejaring Sosial. Journal Universitas PGRI Semarang, 2(2).

Sugiono, V. J., Prayanto, \& Yudani, H. D. (2015). Perancangan Board Game mengenai Bahaya Radiasi Gadget terhadap Anak. Jurnal Desain Komunikasi Visual Adiwarna, 1(6), 1-15.

Suharsimi, A. (2016). Prosedur Penelitian: Suatu Pendekatan Praktik. Jakarta: Rineka Cipta.

Tarigan, H. G. (2011). Pengajaran Pemerolehan Bahasa. Bandung: Angkasa.

Yusuf, S. (2011). Psikologi Perkembangan Anak dan Remaja. Bandung: PT Remaja Rosdakarya. 